\title{
Analysis Knowledge Management System Of Electronic Government South Tangerang Based On Usability Evaluation Using SUMI (Software Usability Measurement Inventory)
}

\section{Thoyyibah. T and Asep Taufik Muharram}

Informatics Department, Faculty of Engineering, Pamulang University, Indonesia

\begin{abstract}
E-Government performance in the application of quality management information communication technology is very necessary. A website-based system is also used to improve the quality of services and community participation in development. The context that becomes the material that needs to be examined is public service, the quality of websites managed by the government and user satisfaction so that there is a two-way interaction between the government and the community. The purpose of this study consisted of three stages which were first to determine the role of E-government by utilizing technology to support the development of a reliable information system in South Tangerang Regency. The second is to find out the extent to which the system is used in South Tangerang E-government through Usability Evaluation using SUMI (Software Usability Measurement Inventory). The method used in this study is a method adopted from the Knowledge Management System Life Cycle. The stages of the method are Evaluate Existing Infrastructure, Form The KM Team, Knowledge Capture, Implement the KM system. The results of this study are in the form of usability values on the E-Government website of South Tangerang and usability testing which becomes a benchmark for the success of a system with score scores for 85 effectiveness categories, 81.5 efficiency and 72.5 satisfaction means the South Tangerang system is in good category.
\end{abstract}

Keyword: E-Government, Knowledge Management System Life Cycle, SUMI (Software Usability Measurement Inventory)

Received 20 September 2019 | Revised 25 December 2019 | Accepted 29 January 2020

\section{Introduction}

Governments around the world are currently facing "pressure" from various parties, to improve the quality of public services and increase active participation in providing information to the public [1]. In addition, the development of science and technology, the government is also required to further improve the performance of public services, especially public services in the form of electronic services or e-service, in this case a website that is expected to be a means of interaction between the government and the community [2]. By implementing an online system,

*Corresponding author at: Informatics Department, Faculty of Engineering, Pamulang University, Indonesia

E-mail address: dosen01116@unpam.ac.id 
many of the benefits obtained include saving costs, because the process of sending data is done online. This system can also be used to access the internet with access to download / upload files faster [3]. Electronic government is the use of information and communication technology in government, so that it can increase the efficiency, effectiveness, transparency and accountability of government implementation [4]. E-Government, the Indonesian government since 2003 has issued a policy on implementing e-government in the form of Presidential Instruction No. 3 of 2003 [5]. Utilization of E-Government aims to provide a reference for the development and utilization of Communication Information Technology (ICT) [6]. In the context of public services, the quality of websites managed by the government is very necessary, this can be seen from the satisfaction of its users so that there is a two-way interaction between the government and the community [7]. But in this case there are still many e-government that use one-way interactions. This needs to be further analyzed to improve the quality of E-Government itself. Overcoming these problems the authors use KMSLC (Knowledge Management System Life Cycle) analysis on South Tangerang E-Government. The KMSLC analysis was carried out in several stages, namely Evaluate Existing Infrastructure, Form the KM Team, Knowledge Capture, Implement the KM system [8]. Thus it can provide improvements to the system through the South Tangerang E-Government knowledge map. Besides that, to find out the quality of user satisfaction, the writer uses SUMI (Software Usability Measurement Inventory) [9]. This is because web-based public services have now become an important part in supporting the success of a government agency, but from this web-based services there are still many that are difficult to use or are not attractive to users and do not function as they should. The reason for this website needs to be measured in order to find out the quality of the website in terms of users and from government standardization that is based on guidelines for the administration of local government websites issued by the Ministry of Communications of the Republic of Indonesia in 2003 [10].

\section{Literature Review}

\subsection{Electronic Government}

Electronic government is an ICT (information, Communication and Technology) government system process, as a tool used to provide ease of communication and transaction processes to citizens, business organizations and between government agencies and their staff. The activities of human life with various sectors have changed. Likewise in the public service sector carried out by the government, the development of information and communication technology has given birth to a model of public service that is carried out through e-government. Bureaucratic and seemingly rigid government services are eliminated through the use of e-Government to become more flexible and more oriented towards user satisfaction. E-Government offers public services that can be accessed 24 hours, whenever and wherever the user is. E-government also allows public services not to be done face-to-face so that services become more efficient. Recognizing 
the enormous benefits of e-Government, the Indonesian government since 2003 has issued a policy on implementing e-government in the form of Presidential Instruction No. 3 of 2003 [11].

\subsection{Knowledge Management}

Knowledge Management consists of a software system and integrates and disseminates information for users for the learning process and making decisions [12]. Besides that knowledge management is a field of study that can improve the process of sharing, channeling, creating, capturing, and understanding knowledge so that knowledge is not in vain [13]. Knowledge management is the maximum result of the source of knowledge needed by someone [14]. Knowledge management is also the process of managing knowledge by capturing, storing and disseminating knowledge using information technology media [15].

\subsection{Knowledge Management System}

Knowledge management systems are the integration of technology and mechanisms developed to support the knowledge management process. Knowledge management systems can be classified into four types, namely the application of knowledge, capture knowledge, share knowledge, discovery of knowledge, the knowledge contained in the system can be used in accordance with their respective fields [14].

\subsection{Benefits of Knowledge Management System}

Some of the benefits of Knowledge Management System on company or organizational technology include [16]:

1. With knowledge oriented, the company can differentiate itself from other companies and can compete effectively in the market.

2. The company can obtain additional benefits derived from operational progress, which focuses on internal activities. These benefits include cost savings, process efficiency, changes in management processes such as changes in behavior, and the benefits of reusing knowledge by other members so that high quality standards can be obtained.

Companies can get additional benefits derived from an increase in the market, which focuses on external activities such as increasing sales performance, saving costs on products and services and increasing customer satisfaction.

\subsection{Usability}

Usability is the assessment of the feasibility of a system based on effectiveness, efficiency and satisfaction in a particular context. The importance of usability to measure the quality of a system's feasibility leads to several testing methods [17]. On the other hand Usability is a measure of a characteristic that describes how effective the user is in interacting with a product [18]. Usability is one of the most important parts to know the characteristics of the quality of a system [19]. In addition, Usability as a quality attribute that assesses how easily the user interface is used, 
thus allowing users to develop tasks clearly, transparently, and useful [20]. According to ISO 9241-11-1998 usability is an assessment of the extent to which a product can be used by users with measures of effectiveness, efficiency and satisfaction in the context of use. Besides that, usability testing is one of the methods used by users to see the level of user convenience in interacting with an information system [21]. To measure application satisfaction, a SUMI (Software Usability Measurment Inventory) questionnaire was used, a questionnaire developed by Collage University [9]. Besides that, usability testing is one of the methods used by users to see the level of user convenience in interacting with an information system [10]. Usability is the interaction between media and users [22]. Planning The initial stage of the system uses usability and user interface [21]. Usability can be seen as one of the criteria to ensure the good and bad levels of a product and problems with usability caused by a lack of knowledge that is often identified when first using the system [17]. Software product usability has become a key factor in software quality [18].

\subsection{Usability}

The method used in the analysis of this system is the method adopted from the Knowledge Management System Life Cycle [8]. The stages of forming a management system in this model include:

1. Evaluate Existing Infrastructure, which is by analyzing the ongoing knowledge management infrastructure.

2. Form The KM Team, i.e. by identifying stakeholders or actors involved in the creation of a knowledge management system.

3. Knowledge Capture, which captures knowledge in the form of tacit or explicit knowledge to be documented. Done with the analysis of books, journals, proceedings to cd or electronic files.

4. Implement the KM system, analyzing the application of knowledge to an ongoing system.

\section{Teoritical Framework}

\subsection{Related Research}

There are several previous studies used as a reference:

a. Research entitled "Roadmap Implementation of Application 2.0 in e-Government towards open government" [23]. This study analyzes the existence of E-Government which is still one-way. This study aims to make a roadmap (phasing) the development of the implementation of web 2.0 applications with technology roadmpping methodology. The results of this study are to open involvement and access to information to the public so that it can realize participatory, collaborative and transparent governance towards open government. 
b. Research entitled "Study of Application of Knowledge Management System Based on SECI Model in E-Mobile Format: Case Study of Indraprasta University PGRI" [24]. This study discusses the implications of the importance of sharing knowledge in lectures. In this case an alternative is needed in the handling of learning for students and lecturers who teach. Knowledge management can be the answer. With this e-mobile based technology the role of the knowledge management system can be increasingly felt. This study uses a SECI method approach that is applied to e-mobile learning. To test the readiness of SECI, it is done by diagnostic. SQA testing on knowledge management system applications created with the aim of measuring the quality of the application.

c. The study, entitled Usability Testing to Improve Mobile Application Interfaces, discusses usability testing in children's applications by using the field observation method by inspecting users how they use the application [25]. Components tested in the form of components of effectiveness, efficiency and satisfaction. The test results show that the method of direct observation in children can increase the usability value of M-Breakfast Nutrition from 78.4\% to $91.1 \%$ so that the application is expected to be in accordance with the objectives so that it can be accepted by users.

d. The study, entitled Application of the Usability Testing Method in Website Evaluation of Prabumulih Municipal Government, discusses the extent of mistakes made by users and measures the contents of the website based on the implementation of local government website issued by the Ministry of Communication of the Republic of Indonesia in 2003. The results of the study this also shows that $100 \%$ learnability, $66.66 \%$ efficiency, $58.33 \%$ memorability, $53.33 \%$ satisfaction that can be used by users [26].

e. The study, entitled Measurement of Usability of Financial Information Systems Case Study: Ambassador of Internal Transaction Discourse (DuWIT), discusses how much the level of understanding and difficulty of users in using the transaction system through the DuWIT application. The results of this study indicate usability above $72 \%$ so that this application is declared user friendly [28].

\section{Methodology}

The system development method used is the method adopted from KM System Life Cycle contained in the second Edition of Knowledge Management book [8]. The method in Figure 1 consists of Evaluate Existing Infrastructure, Form the KM Team, Knowledge Capture, Implement the KM system. 


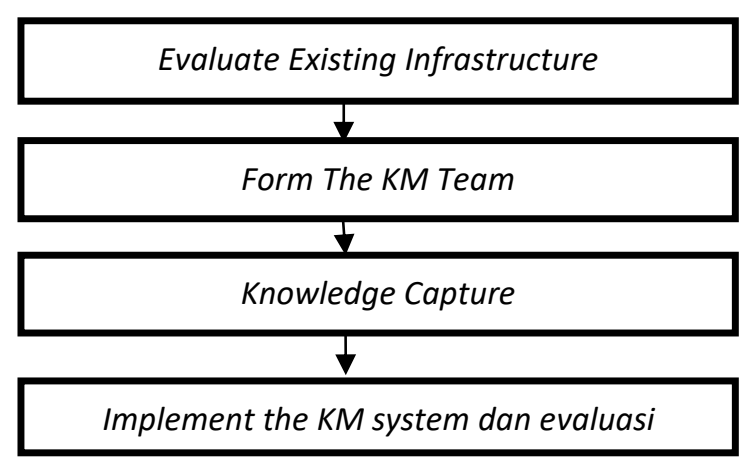

Figure 1. Research Method

The stages of the research method consist of:

a. Evaluate Existing Infrastructure

The Existing Infrastructure Evaluate Process is the first stage of the KM System Life Cycle. This process is done by looking at the characteristics of users of the South Tangerang Information System.

\section{b. The KM Team Form}

Integrated knowledge management system technology and mechanisms developed to support the knowledge management process [11]. The KM Team Form is conducted by identifying who is involved in the process of designing the South Tangerang system.

\section{c. Knowledge Capture}

Knowledge Capture is done by creating a knowledge map on the South Tangerang system. Where each map is integrated and interconnected. It aims to reuse the knowledge that exists in a system, thus turning information into useful knowledge [12]. Through Knowledge Capture can also convert knowledge that is tacit and explicit knowledge [13].

\section{d. Implement the KM system and evaluate}

Implement the KM system is done by doing a screenshot of the South Tangerang system. It also explains the results of the implementation of knowledge used in the South Tangerang system. And the evaluation is done by usability analysis. Usability as a quality attribute that assesses how easily the user interface is used, thus allowing users to develop tasks clearly, transparently, and useful [14]. Usability is also an assessment of the extent of the feasibility of a system based on effectiveness, efficiency and satisfaction in certain contexts. The importance of usability to measure the quality of a system's feasibility leads to several testing methods [15]. On the other hand Usability is a measure of a characteristic that describes how effective the user is in interacting with a product [16]. Usability is one of the most important parts to know the characteristics of the quality of a system [17]. 


\section{Results}

a. Evaluate Existing Infrastructure

The characteristics of users of the South Tangerang Information System in the general public. The sampling technique of respondents is using snowball sampling technique. The sampling technique is initially small in number, then this sample directs his friends to be sampled as well so that the sample becomes large [18]. The author uses respondents as much as 10. In this study only displays the results of the general public questionnaire. The South Tangerang web page is www.tangerangselatankota.go.id. Figure 2 is the initial display page of the web of design principles in general.

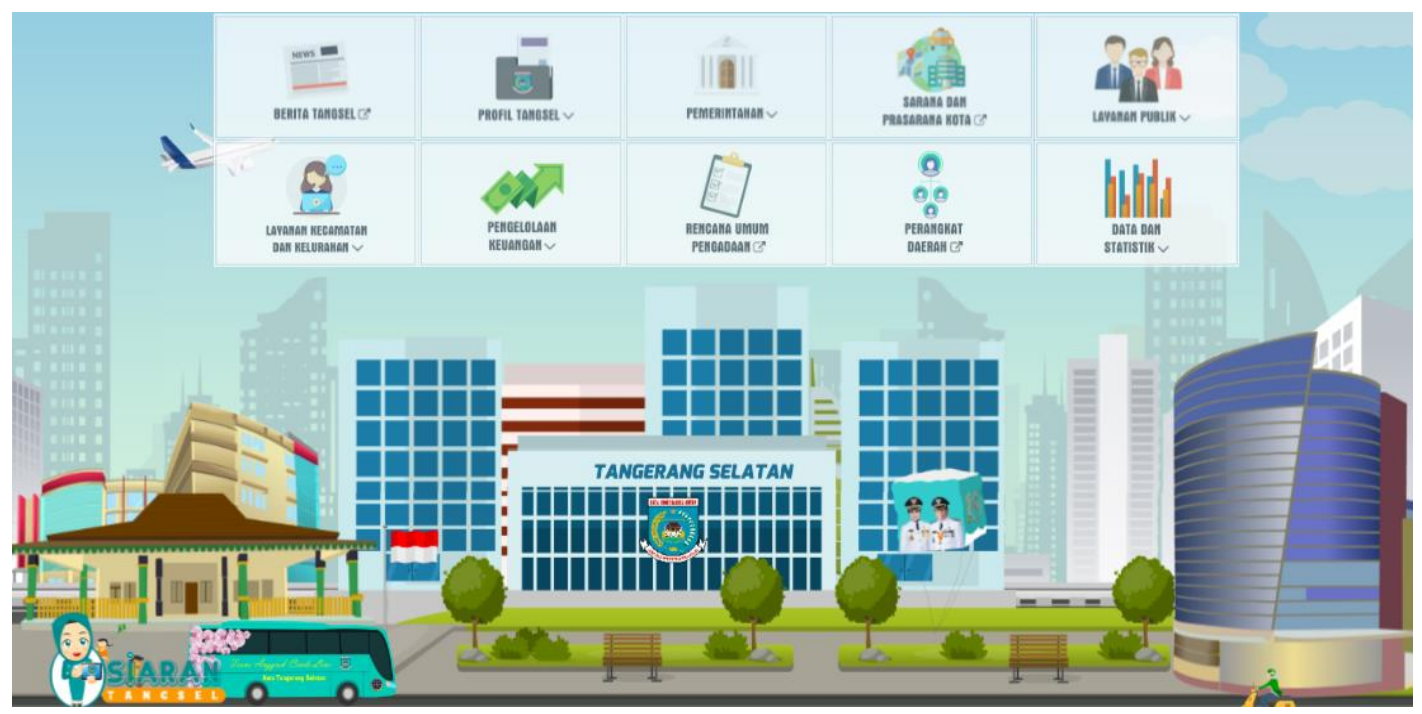

Figure 2. Starting page of the South Tangerang web

b. The KM Team Form

The KM Team Form is conducted by the programmer and system analyst involved.

c. Knowledge Capture

Knowledge maps in the South Tangerang system are tangsel news, South Tangerang profiles, government, facilities and infrastructure of the city, public services, sub-district and subdistrict services, financial management, general procurement plans, regional instruments, data and statistics. tangsel news will refer to https://berita.tangerangselatankota.go.id/.

Tangsel profile contains regional symbols, history, geography and demographics. governance contains the mayor's profile, deputy mayor's profile, vision and mission, organizational structure, list. City facilities and infrastructures will open the page https://berita.tangerangselatankota.go.id/main/content/index/sarana_prasarana/23. public services include LPSE, PPID, Licensing, E-SPRT, E-SPTPD, PBB and BPHTB, RSUD, Legal Products (JDIH), tangsel broadcast, SIAKCAPIL, DISHUB ATCS, SIMPUS, BANSOS GRANTS, Sports Space, Market Price Monitor, SIPADUKEREN, Online Course, sub-district and sub-district services will open the siantar service page, pamor service, subdistrict address, sub-district address. Financial management opens the APBD link and Daetah Financial Reports, the general procurement plan will open the 
https://sirup.lkpp.go.id/sirup/home/penyedia/kldi/D47 page, which is a government procurement/service policy agency. regional devices will open the page https://berita.tangerangselatankota.go.id/main/skpd. Data and statistics will open economic, social, political, legal and human rights subsections, tables and graphs and ICTs.

d. Implement KM System and evaluation

Implement KM system is done by doing a screenshot of the South Tangerang system. Here are some views of the South Tangerang system. Figure 3 shows the facilities and infrastructure of the South Tangerang area.

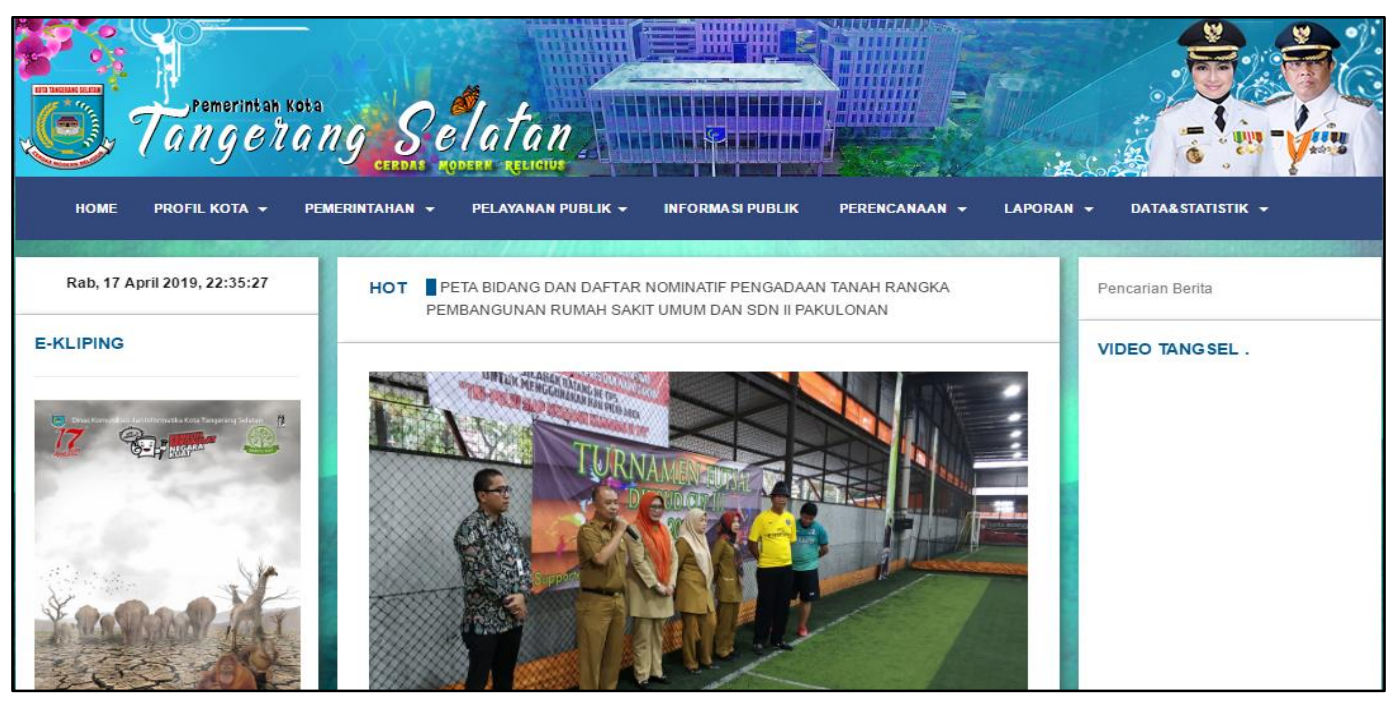

Figure 3. South Tangerang Facilities and Infrastructure

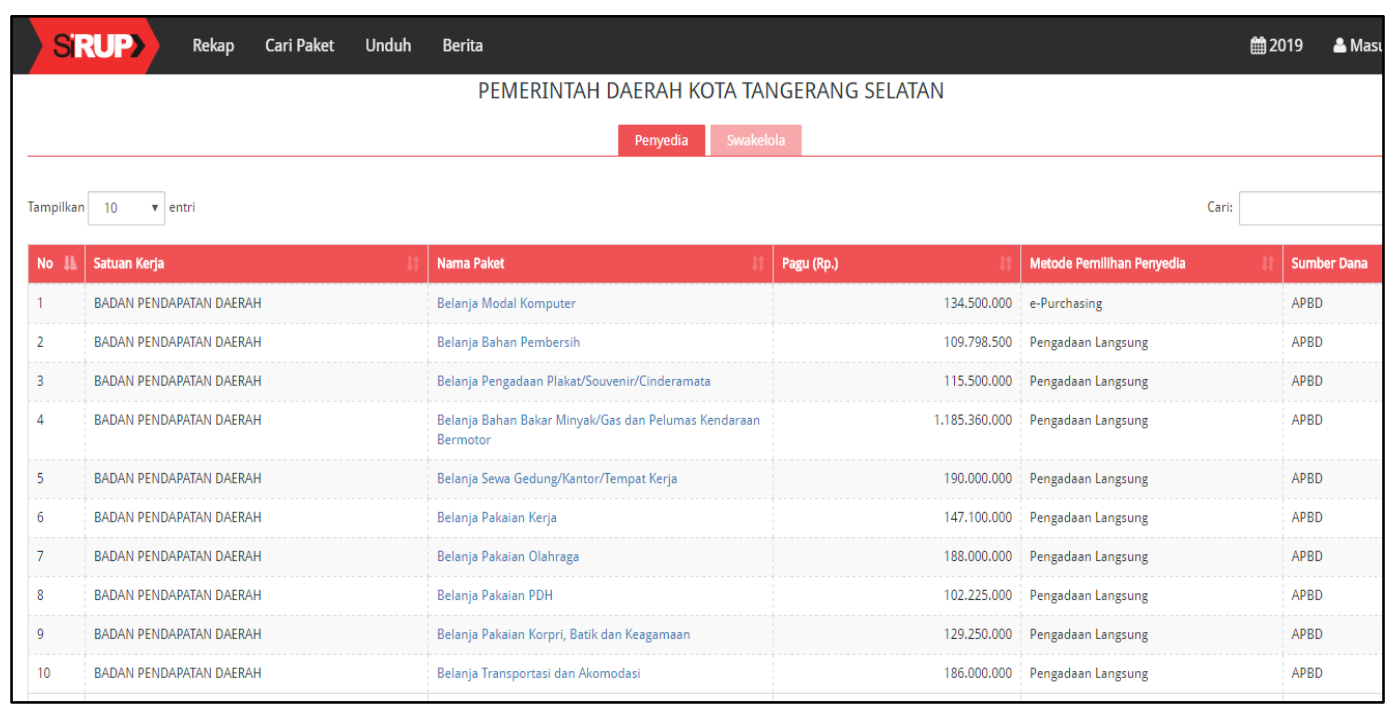

Figure 4. General and procurement section page 
Figure 4. Is a general section page and procurement. This page is a breakdown of the local revenue agency.

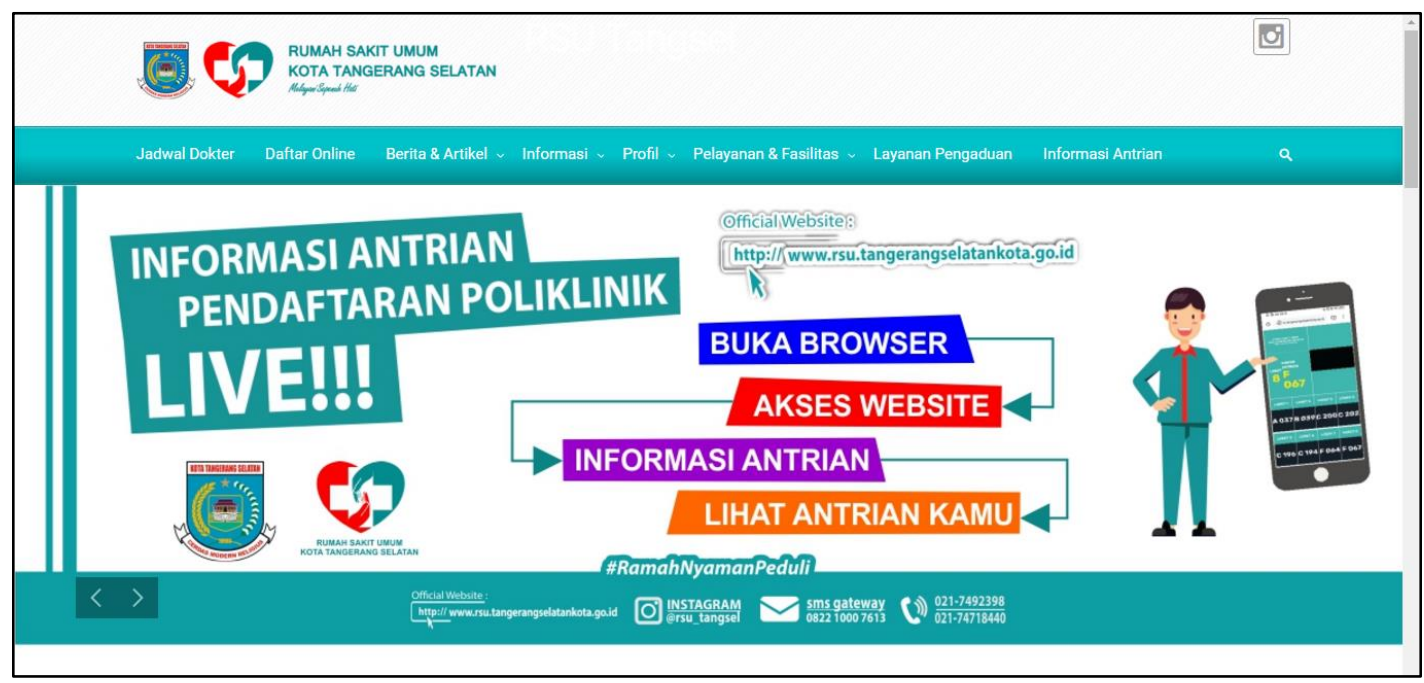

Figure 5. Public services in the form of hospitals

Figure 5 is a picture of public services integrated with the South Tangerang web. On this page the public can register online in advance, and see the schedule of doctors who practice. The evaluation in this study was carried out with the SUMI (Software Usability Measurement Inventory) questionnaire. The results of the questionnaire displayed in this study with 10 respondents in the category of the general population of South Tangerang. The categories used for the questionnaire are effectiveness, efficiency and satisfaction. The linker used in the questionnaire is SS (Strongly Agree) ie multiplied by 4, S (Agree) multiplied by 3, TT (Don't Know) is multiplied by 3, TS (Disagree) is multiplied by 0 . The overall result with the formula 2.5 times total . So that it is stated that if the whole SS box becomes 100, then the total totals are sorted from the smallest to find the Median. Table 2 is the effectiveness table, Table 3 efficiency and Table 4 Satisfaction with the South Tangerang information system. Table 5 is the result of a median calculation of effectiveness, efficiency and satisfaction.

Table 2. effectiveness

\begin{tabular}{cccccccccc}
\hline 1 & 2 & 3 & 4 & 5 & 6 & 7 & 8 & 9 & 10 \\
\hline 70 & 70 & 100 & 85 & 100 & 100 & 80 & 85 & 75 & 75 \\
\hline
\end{tabular}

Table 3. efficiency

\begin{tabular}{cccccccccc}
\hline 1 & 2 & 3 & 4 & 5 & 6 & 7 & 8 & 9 & 10 \\
\hline 52 & 50 & 100 & 85 & 100 & 83 & 100 & 75 & 80 & 75 \\
\hline
\end{tabular}

Table 4. satisfaction

\begin{tabular}{cccccccccc}
\hline 1 & 2 & 3 & 4 & 5 & 6 & 7 & 8 & 9 & 10 \\
\hline 80 & 70 & 100 & 100 & 68 & 30 & 75 & 85 & 52 & 70 \\
\hline
\end{tabular}


Table 5. Median of effectiveness, efficiency and satisfaction

\begin{tabular}{cccc}
\hline No & effectiveness & efficiency & satisfaction \\
\hline 1 & 70 & 50 & 30 \\
2 & 70 & 52 & 52 \\
3 & 75 & 75 & 68 \\
4 & 75 & 75 & 70 \\
5 & 80 & 80 & 70 \\
6 & 85 & 83 & 75 \\
7 & 85 & 85 & 80 \\
8 & 100 & 100 & 85 \\
9 & 100 & 100 & 100 \\
10 & 100 & 100 & 100 \\
\hline Median & 85 & 81.5 & 72.5 \\
\hline
\end{tabular}

\section{Results}

Analysis of the South Tangerang information system was developed using the KMSLC method approach with the Usability Engineering approach. With this knowledge-based system users can see and download information that is useful for users. The results of this analysis are in the form of a South Tangerang knowledge management system in which data sources used also include general and procurement section documents, facilities and infrastructure and others. By using the SUMI questionnaire obtained scores for the category of effectiveness 85 , efficiency 81.5 and satisfaction of 72.5. Scores from each category are above the average SUMI provisions, which means that the usability of the Tangerang Selatan information system is good.

\section{Acknowledgement}

The author thanks to University of Pamulang and the Directorate General of Strengthening for Research and Development, Ministry of Research, Technology and Higher Education who have funded this research as the beginner lecturer grant scheme in 2019.

\section{REFERENCES}

[1] Holle ES, 2011. Pelayanan Publik Melalui Electronic Government: Upaya Meminimalisir Praktek Maladministrasi Dalam Meningkatkan Public Service. Jurnal Sasi. Volume 17 Nomor 3..

[2] Aprilia SN, Wijaya AF, Suryadi. 2014. Efektivitas Website Sebagai Media E-Government dalam Meningkatkan Pelayanan Elektronik Pemerintah Daerah (Studi pada Website Pemerintah Daerah Kabupaten Jombang). Wacana jurnal. Vol 17, No 3: 1411-0199. 
[3] Susena E, Lestari DA. 2016. Efektivitas Penerapan Electronic Government Terhadap Pelayanan Publik Di Kabupaten Sragen. Jurnal SAINSTECH Politeknik Indonusa Surakarta. Volume 2 Nomer 6: 2355-5009.

[4] Yuhefizar. 2010. Tinjauan Penerapan E-Government di Provinsi Sumatera Barat. Poli Rekayasa Jurnal . volume 5, Nomor 2: 1858-3709.

[5] Hartono, Utomo D, Mulyanto E. 2010. Elecronic Government Pemberdayaan Pemerintahan dan Potensi Daesa Berbasis Web. Jurnal Teknologi Informasi. Volume 6 Nomor 1: 1414-9999.

[6] Tampubolon LPD. 2010. Pemeringkatan E-Government Indonesia (PEGI) dan Pemanfaatan Teknologi Informasi di DKI Jakarta. Jurnal Sistem Informasi. ISSN 23554614.

[7] Abadi TW, Prajarto N, Guntoro B. 2014. Performance E-Government Untuk Peningkatan Partisipasi Masyarakat Dalam Pembangunan Infrastruktur di Kabupaten Sidoarjo. Kawistara jurnal. Volume 4, No. 3: 237-248.

[8] Awad EM, Ghaziri HM. 2010. Knowledge Management. Prentice Hall.

[9] Veenendaal E. 1998. Questionnaire Based Usability Testing. Conference Proceedings European Software Quality Week; Brussels, November 1998. Valkeenswaard: Improve Quality Services Waalreseweg.

[10] Saputra E, Mzalisa Z, Andryani R. 2014. Usability Testing Untuk Mengukur Penggunaan Website Inspektorat Kota Palembang. Jurnal Teknik Informatika.

[11] Hartono, Utomo D, Mulyanto E. 2010. Elecronic Government Pemberdayaan Pemerintahan dan Potensi Daesa Berbasis Web. Jurnal Teknologi Informasi. Volume 6 Nomor 1: 1414-9999.

[12] Rhem AJ. 2006. UML For Developing Knowledge Management Systems. Boca Raton New York : Taylor \&Francis Group.

[13] Gottschalk P. 2006. Stage of Knowledge Management Systems In Police Investigations. Knowledge Based Systems Journal. Vol 19: 381-387.

[14] Fernandez IB, Sabherwal R. 2010. Knowledge Management: System and Processes. England: M.E. Sharpe.

[15] Lai LF. 2007. A Knowledge Engineering Approach To Knowledge. Management. Information Sciences an international journal. Vol. 177: 4072-4094.

[16] Martin EW, Brown CV, Dehayes DW, Hoffer JA, Perkins WC. 2005.Managing Information Technology. Prentice-Hall.

[17] M Bella A, Saputra MC, Pinandito A. 2016. Analisis Usability Pada Website Universitas Brawijaya Dengan Heuristic Evaluation. Jurnal Teknologi Informasi dan Ilmu Komputer (JTIIK). Volume 3 Nomer 3: 188-193.

[18] Sriwulandari A, Hidayati H, Pudjoatmojo B. 2014. Analisis dan Evalusi Aspek Usability pada Web HRMIS Telkom University Menggunakan Usability Testing. E-Proceeding of Engineering. Volume 1 Nomer 1: 2355-9365.

[19] Diah NM, Ismail M, Ahmad S, Dahari MKM. 2010. Usability Testing for Educational Computer Game Using Observation Method. Computer and Mathematical Science Journal. Vol 1: 4244-5651.

[20] Nielsen J. 2012. Usability 101: Introduction to usability. Alertbox. [Internet].[diunduh 2019 April 29]. Tersedia pada http://www.nngroup.com/articles/usability-101introduction-to-usability/ 
[21] Henriyadi, Mulyati R. 2014. Usability Testing Sistem Informasi Studi Kasus Aplikasi Repository Publikasi Badan Penelitian dan Pengembangan Pertanian. Jurnal Pusat Perpustakaan Dan Penyebaran Teknologi Pertanian.

[22] Nonaka IT, Takeuchi. 1995. The Knowledge Creating Company: How Japanese Companies Create the Dynamics of Innovation. Oxford. Oxford University Press.

[23] Supradono B, Hanum AN. 2012. Roadmap Implementasi Aplikasi 2.0 pada E-goverment menuju pemerintahan terbuka.Seminar Nasional Aplikasi Teknologi Informasi (SNATI). 1907-5022

[24] Yudha B. 2015. Kajian Penerapan Knowledge Management System Berbasis SECI Model Dalam Dormat E-Mobile: Studi Kasus Universitas Indraprasta PGRI. Kajian Penerapan Knowledge Management. 279-289:1979-276x

[25] Sianturi SK, Nurhadryani Y, Hermadi I, Khotimah H. (2013). Jurnal Ilmu Komputer AgriInformatika. Volume 2 No. 2 Hal 83-93: 2089-6016.

[26] Hidayat W, Radis HY, Efendi U. (2014). Penerapan Metode Usability Testing dan Evaluasi Situs Web Pemerintahan Kota Prabumulih. Jurnal Teknik Informatika Universitas Bina Darma Palembang.

[27] Handiwidjojo W, Ernawati L. (2016). Pengukuran Tingkat Ketergunaan (Usability) Sistem Informasi Keuangan Studi Kasus: Duta Wacana Internal Transaction (DuWit). Jurnal Informatika dan Sistem Informasi. Vol. 2 No. 1:2460-1306 